\title{
Research on the Relationship between Confucianism and the Transformation and Upgrading of China's Tourism Industry
}

\author{
Zhiyu Qin \\ Rizhao Polytechnic \\ Rizhao, China
}

\begin{abstract}
This article, from the Confucian culture and its core thoughts, firstly analyzes the Confucian thought of "benevolence" and "righteousness", and then analyzes the concept of tourism in Confucianism. Confucianism has been precipitated as cultural psychology in the heart of Chinese. The tourism concept has an important practical significance to the transformation and upgrading of our tourism industry. The article focuses on the analysis of the relationship between Confucianism and the transformation and upgrading of our tourism industry from guiding ideology, industrial integration, ecological consciousness and system construction based on the analysis of the transformation trend of our tourism industry.
\end{abstract}

Keywords-Confucianism; tourism concept; industry transformation; relationship research

\section{INTRODUCTION}

In today's ecological environment, ecologists begin to search the root of ecological crisis in order to alleviate it from the root. This task is not only the responsibility of natural science, but also that of humanities. We try to find resolution from our cultural resources. Confucianism is one of precious cultural resources for us to consult.

\section{CONFUCIAN CULTURE AND ITS CORE THOUGHTS}

Confucianism is a school founded by Confucius during the Spring and Autumn period. Since then, Confucius established the Confucianism, and later Mencius and Dong Zhongshu carried forward Confucian thoughts, and opened up a number of branches, such as, the supplement of Mencius and Xunzi, the perfection and development of study of Confucian classics of Western Han and Eastern Han Dynasties, idealist philosophy of the Song and Ming Dynasties and pragmatism of Ming and Qing Dynasties. It became the mainstream ideology for rulers to control China, for Confucian culture values justice above material gains, and advocates reviving the extinguished states and restoring families whose lines of succession had been cut off. It has been precipitated as cultural psychology deeply in the heart of Chinese. It has a profound impact on Chinese culture and social life.

In spreading, Confucianism taught historical records and thoughts and educated officials and scholars in the aspects of self-cultivation, family planning, ruling the country and governing the world. Meanwhile, it also taught various ritual systems and moral norms in patriarchal society. Although different people have different opinions in their school, the core thoughts are of "benevolence" and "righteousness".

Confucius praised "benevolence" highly. He thought it was the highest level of morality and the ultimate goal of gentleman in self-cultivation. Confucius's "benevolence" is a kind of thought. Gentlemen with "benevolence" follow rites in behavior, pursue kindness in thought and broadness and calmness in mind. It is the rules of conduct of gentleman. It advocates the golden mean that gentleman don't advance in rush and shrink back, but weighing the pros and cons appropriately.

Mencius was the first man who developed Confucianism. Mencius advocated "righteousness" highly. "Righteousness" of Mencius comes from Confucius's "benevolence". "Righteousness", which mainly tells us what is a gentleman and how to be a gentleman, and how to be kind as a gentleman "Everyone has something he/she doesn't want to do. That help him/her do what he/she is willing to do is righteousness". It should be said that Mencius's "righteousness" is more free and easy.

\section{TOURISM CONCEPT IN CONFUCIANISM}

The modern tourism industry develops rapidly. At the same time, it also has a serious impact on the social culture and environment in the tourist area. In order to solve the problems of tourism environment, ecology and sustainable development, we need to change people's concept from the ideological level and realize the harmonious coexistence of man and nature. The Confucian thought puts forward such ecological thoughts as "cherishing life, loving all things", "taking with a plan, using abstemiously", "reverence for life", and so on. It is of important guiding significance for the society to coordinate the relationship between man and nature.

\section{A. The Thought of Ecological Tourism in Reverence for Life}

In traditional Confucian culture, Confucius's thought of "knowing the mandate of the heaven" has been recorded in Analects of Confucius and Historical Records: one shall know the mandate of the heaven in his fifty. It also refers to the laws of nature. Because of knowing the laws of the nature, one can 
revere the mandate of the heaven. It requires human beings to take the responsibility of ecological ethics by making use of nature and protecting the nature. In the practice of tourism development and management, we should follow the development law of the nature, maintain the original state of tourism resources, and develop tourism moderately under the premise of protection.

\section{B. View of "Benevolence and Rite" in Confucian Culture}

The essential meaning of "benevolence" includes respecting each other and cherishing each other. In the ecological ethics of tourism, we shall not only know the inherent right to the development of tourism resources, but also protect the natural environment and humanistic environment of tourism resources. The existence of species diversity is the source of rich tourism resources, which can meet the diversified and personalized needs of tourists.

\section{The Aesthetic View of "Loving Mountains and Waters"}

Confucius loved to scale the summit and face the water, for it could broaden his horizon, increase knowledge, and cultivate his temperament. It has formed a kind of aesthetic consciousness based on ecological value. Confucius said: "the wise man delights in water, and the benevolent man delights in mountain", which reflects that Confucius understood the intrinsic nature of man from the nature. The similarities arouse people's moral awareness, which integrates education of ecological ethics into moral education. It has an important role in the cultivation of people to love nature and protect nature.

\section{Consumption Concept of "Being Frugal Rather than Extravagant"}

Confucius advocated frugality and opposed extravagance. He treated frugality as a virtue of gentlemen. He said, "gentlemen shall not seek full satiation and ease". Confucius put forward his consumption concept under the environment at that time. It helped people protect natural environment and resources, meanwhile he also asked the ruler to give people more benefits and make example in frugality. His concept has an importance practical significance for the maintenance of people's daily life and the protection of natural environment in the productivity level at that time.

\section{ANALYSIS ON TRANSFORMATION TREND OF CHINESE TOURISM INDUSTRY}

By the period of the 13th Five-Year Plan, Chinese per capita GDP will exceed $\$ 10$ thousand. China starts from "stand up" to "be rich and strong". China also will fully enter into the Leisure Society (when per capita GDP reached 6000 U.S. dollars or more, the country will enter the era of leisure). This will bring a larger tourism market. The 19th National Congress of CPC reported "support the optimization and upgrading of traditional industries, accelerate the development of modern service industry, improve the level to international standards, and promote China's industries to mid-high section of the global value chain". It, first of all, is reflected in consumption of the mass. Travel has become an important part of people's life. DIY tour and self-driving travel have become main travel ways. Secondly, pay more attention to the quality on the demand. The demand for service facilities and surrounding environment is higher and higher. The demand for personalized tourism products and mid-end and high-end tourism products is larger and larger. Third, the competition of tourism market becomes increasingly internationalized. The tourism industry will further participate in the international division of market. Countries will launch various policies and measures to promote the globalization of tourism market and internationalization of competition. Finally, the extensive application of modern information technology also promotes the depth of integration of tourism industry and cultural industry, and other industries. The modernization of industrial system becomes the inevitable trend of tourism development.

In essence, Confucianism is a typical ecological ethics, which contrasts sharply with the emphasis on individual heroism in capitalist countries, which provides nourishment for the development of modern tourism.

\section{THE RELATIONSHIP BETWEEN CONFUCIANISM AND THE TRANSFORMATION AND UPGRADING OF TOURISM INDUSTRY}

\section{A. Respecting for Ecological Laws}

The industry upgrading and transformation shall be limited in the bearable scope of the nature. It shall respect natural laws and keep a harmonious relationship with surrounding. Confucian advocated the thought of "harmony between man and nature". It attaches great importance to thought: "the benevolent take the universe as a whole". It takes the universe as an organic life system. It regards respecting nature and protecting nature as the highest standard in human morality. We shall also value it in the upgrading and transformation of tourism industry. Once we violate the laws of natural ecology, it will certainly shake the foundation of human and affect the development of human, and endanger the survival and development of tourism.

\section{B. Setting up the Correct Concept of Transformation under the Guidance of Confucianism}

Confucianism provides a cultural source for philosophies of tourism development and management. The view of "benevolence and rite" in Confucianism allows developers and managers to re-examine the relationship between human beings and environment, so that they avoid making mistake of "pollution first and then control". In the process of development and management, we shall respect and love surrounding environment, protect biodiversity and make global planning and integrate all elements, and implement the development of global tourism into urban construction, land use, ecological protection and other types of planning.

Strengthen the law enforcement of tourism, strengthen the propaganda of civilized tourism, perfect the comprehensive evaluation of tourism industry development, and pay attention to the protection of the humanities and natural environment. To develop tourism shall be built in carrying capacity of the environment and society, and do not blindly pursue economic benefits, and develop. Pay attention to the "intergenerational equity" of tourism development and management. Do not 
pursue grandiose achievements, or only focus on the immediate development, and leave the remaining issues to the next manager to deal with.

\section{Using Confucianism to Guide Cultural Innovation and Promote Industrial Convergence}

Implement the "Travel $+"$ strategy. Promote the integration development of tourism industry and cultural industry. Confucianism advocates "loving mountains and waters", which reflects that Confucius understood the intrinsic nature of human from the nature. The similarities can effectively arouse people's moral consciousness.

Develop experience tourism, study and research tourism and ancient-village leisure travel with the support of art exhibition and the intangible cultural heritage protection, integrate the development of tourism industry and cultural creative development, develop cultural performance tourism, promote the show of tourism scene and build festival tourism brand. In the process of industrial integration and development, the ecological protection principle runs through the entire tourism product development process. Focus on the environmental protection on food, housing, tourism, shopping, entertainment and other product development in the whole industry chain integration, and use clean energy as much as possible.

\section{Strengthening the Ecological Awareness of Tourists and Local Residents}

Tourists and local residents directly involve in tourism activities, and directly contact with all kinds of tourist resources. So, it is necessary to improve tourists' consciousness on Chinese tradition and culture. On one hand it helps them understand local tourism resources and culture and the propaganda of the tourism culture. On the other hand, tourists with high ecological consciousness will protect local tourism resources and traditional culture consciously.

For the residents in the tourism area, higher cultural literacy and ecological awareness can keep and maintain the "original flavor" of the culture fundamentally, so as to ensure the sustainable development of tourism. Therefore, it is of great practical significance to strengthen the ecological awareness of tourists and local residents, make them fully aware of the interdependence between the protection of local resources and personal life, and strengthen the ecological consciousness of "harmony between man and nature" in the development of tourism industry.

\section{E. Government Departments Should Formulate Effective Management Measures and Build an Effective System}

First of all, tourism management departments shall establish a reasonable system and ethnic standard for the sustainable development of the tourism industry from the longterm perspective. For instance, establish relevant laws and regulations to protect traditional folks and cultural heritages. Referring to domestic and international standards, formulate our own norms and standards for tourism behaviors to guide travel activities of our people. Build a monitoring and evaluation system for the management of tourism resources and make laws for people to follow in the development and utilization of tourism resources and ecological tourism activities.

At the same time, define responsibilities and obligations of the government management departments, market tourism enterprises and local departments of tourism resources in the tourism development area according to the principle of the sustainable development, including the development planning, formulation of measures, promotion and sales, management, process evaluation, result evaluation and so on. Form an operating and control mechanism of clear responsibility and division of labor. And ensure "generational equity" and "intergenerational equity" in the development of tourism industry.

\section{CONCLUSION}

In short, although Confucianism was generated long before, its thoughts surpass the limit of era and shine with glory. It has eternal values for us. It has an importance guiding significance in the transformation and upgrading of the tourism industry. The transformation and upgrading of tourism industry is a comprehensive and practical task, and has an important meaning for the improvement of people's living standard and enrichment of people's life content. Therefore, it is meaningful to mine the deep connotation and time significance of Confucianism. It has real meaning for us to build modern and ecological tourism ethnics, promote the effective supply of tourism products, develop high-end products, optimize the tourism supply structure and lift level of coordination of supply and demand.

\section{REFERENCES}

[1] Shen Zuxiang, Tourism and Chinese Culture. Beijing: Tourism Education Press, 1996.1-17.

[2] Pan Baoming, Zhu Anping. Chinese Tourism Culture. Beijing: China Tourism Publishing House, 2001. 20 - 21.

[3] Ren Shahua, Liu Xiaohua. Cultural Interpretation of Environmental Ethics - Ecological Wisdom in Ancient China. Changsha: Hunan Normal University Press, 2004.

[4] Li Hongbo, Eco-tourism Environmental Ethics Should Be Regulated. World Culture, 2002, (2): 66-67.

[5] Xu Jiacong, $\mathrm{Xu}$ Shumei. Coupling of Confucianism and Tourism Industry. Cultural Studies, 2015.18. 